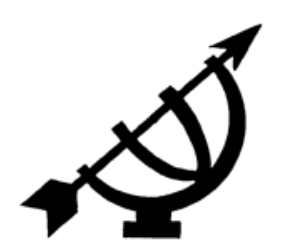

\title{
The desire for the ineffable: on the myth of music as absolute
}

\author{
W. Froneman \\ School of Music \\ Potchefstroom Campus \\ North-West University \\ POTCHEFSTROOM \\ E-mail: Willemien.Froneman@nwu.ac.za
}

\begin{abstract}
The desire for the ineffable: on the myth of music as absolute

This article proposes to establish and critique connections between religious and musico-aesthetic conceptions of ineffability by exploring the link between neoplatonic thought and romantic aesthetics. The central thesis is that recourse to the ineffable is often made by resorting to theological tenets and, consequently, that romantic aesthetics, although desperately trying to disengage itself from theological thinking, can in fact be interpreted as being inextricably bound up with it. Taking Plotinus' conception of the relationship between the "One" and "Intellect" as model, the romantic conception of the absolute is revealed to be a fallacy. It is shown that claims of the ineffability of music not only locate music as a false absolute, but also confer on music a quasi-religious authority. This results in an ungrounded secular faith in the power of music and the mastery of its composer-god to lead mankind to the truth. Untangling the myths of ineffability leads the way to a detranscendentalised conception of music with performance at its centre.
\end{abstract}

\section{Opsomming}

Die soeke na die onsegbare: oor die mite van musiek as die absolute

Hierdie artikel poog om konneksies tussen religieuse en musiek-estetiese beskouings oor die onsegbare uit te wys en te kritiseer, deur die gebruik van die term in onderskeidelik neoplatoniese en romantiese denke te ondersoek. Die sentrale hipotese is dat 'n diskoers rondom die onuitspreeklike dikwels op teologiese uitgangspunte moet steun en gevolglik, dat die 
romantiese estetika geïnterpreteer kan word in 'n nóú verbintenis met teologiese denke, ten spyte van 'n amper desperate poging tot die teendeel. Met Plotinus se beskouing oor die verhouding tussen die "Een" en die "Intellek" as model, word aangetoon dat die romantiese beskouing van die absolute 'n mistasting is. Daar word daarop gewys dat bewerings oor die onsegbaarheid van musiek nie alleen musiek as die absolute daarstel nie, maar dat 'n kwasi-religieuse gesag daardeur aan musiek verleen word. Gevolglik het 'n onbegronde sekulêre geloof in die krag van musiek ontstaan en in die vermoë van die komponis-god om die mensdom na die waarheid te lei. Deur die mites rondom die onsegbaarheid van musiek uit te wys, word die weg gebaan vir 'n gedetransendentaliseerde beskouing van musiek met uitvoering as die primêre fokus.

\section{Religion and ineffability}

The concept of the ineffable was born in ancient Greek philosophy of religion and has been closely associated with religious thought ever since. This association might be said to rest solely on the fact that the ineffable as concept holds a central place in religious discourse. It was, after all, in writing about the One, the absolute God, that Plotinus developed the first detailed theory of the ineffable. In modern times, however, we do not reserve the category of the ineffable exclusively for talking about God. We are often lost for words when talking about our feelings. We cannot describe situations adequately, colours lose their hues in conversation, but above all, our experience of music seems for the most part to be beyond words.

Other compelling arguments, however, suggest that the relationship between ineffability and religion can be observed in ways apart from direct appeals to the ineffability of God. According to one such argument by Moore (2003), the link between ineffability and religion can also be explored by acknowledging that attempts to put states of ineffable knowledge into words very often result in a language that has significant religious resonances (Moore, 2003:167):

The temptation to treat ineffable states of knowledge as effable is of a piece with the urge which we humans have to transcend some of our most basic limitations. For the very fact that we have such ineffable knowledge, which enables us to make sense of things, is an indication of our radical finitude ... Eventually it becomes a temptation to talk of God. 
In other words, even though knowledge of God is not the only ineffable state of knowledge, the temptation to translate any ineffable state of knowledge into words, like our experience of colour or music, often goes along with "images of unlimitedness and infinitude" (Moore, 2003:167). In more general terms, the "images of unlimitedness and infinitude" that are conjured up by claims of ineffability can be described as the longing for an absolute, godlike entity.

Using the link between ineffability and the absolute in Plotinus' Enneads (c. 250-270) as a model for the ideal relationship between the sublime and the beautiful, I will show the deficiencies of the romantic notions of subjectivity and autonomous art - especially as they relate to the ineffable. I am not arguing here that the romantic notion of the ineffable has its direct lineage in neoplatonic thought (although this is indeed a plausible theory), rather, I am juxtaposing two distinct moments in the history of the ineffable in order to show how the concept has been impoverished by the romantic preference for the sublime. In turn, what constitutes musical meaning has been impoverished too. In section 5, I discuss the survival of the romantic notion of the ineffable in current musicology, and suggest an alternative approach to the study of music.

\section{The ineffable and the absolute}

From Plotinus' Enneads, his meditations on the existence of the One or the Absolute, much can be learned about the more general relationship between claims of the ineffable and the absolute. Instead of creation ex nihilo, Plotinus proposes that the world comes into existence through "emanation" from the One. The One is, however, in no way impoverished or diminished in the process. In order to find the way back to the One, Plotinus proposes three "primary hypostases", three phases of reality, through which the mind must move before finding ultimate rest in God. These hypostases, in ascending order, are soul, intellect and the One (Plotinus, 1988:1). For Plotinus the One is the ultimate cause of all things and an absolutely simple reality. The One therefore lies beyond the realm of knowledge and discourse: the One is unknowable and ineffable (O'Meara, 1993:54)

In the first instance, Plotinus' methodology makes it clear that characterising absolutes can only be done negatively. If something is truly absolute, it follows logically that it should be beyond characterisation, because if it is like something else it ceases to be absolute. In talking about the One we can only say what it is not. Therefore, even though the link between the ineffable and the absolute 
might be construed as essentially arbitrary, the converse is not true. An absolute is only truly absolute when it is ineffable.

Contemplating the ineffable in relation to the absolute also reveals a second, more psychological implication. In a sense Plotinus is faced with a seemingly irresolvable aporia: if the One is ineffable and can only be described negatively, how is it possible to speak about it in any meaningful way? In O'Meara's (1993) view the answer can be found in the following passage from the Enneads (O'Meara, 1993: 56):

Since to say it [the One] is the cause is to predicate an attribute not of it, but of us, in that we have something from it, which exists in itself. But he who speaks accurately should not say 'it' or 'exists', but we circle around it on the outside, as it were, wishing to communicate our impressions, sometimes coming near, sometimes falling back on account of the dilemmas that surround it.

According to O'Meara (2000:247), Plotinus never claims that we actually think and speak the unthinkable and ineffable

... rather, when we are thinking and speaking the One, we are actually thinking and speaking of ourselves, expressing something in us which can be thought and said, but which refers beyond itself, to the One.

Speaking about the absolute thus inadvertently sets up the speaking subject in relation to that absolute, so that what is said is in fact an indication of the subject's deficiency and need (O'Meara, 2000:247). Conversely, the absolute takes on a messianic character as the only remedy to this sense of eternal lack. Ineffability refers not only to the radical finitude of the subject in the shadow of the absolute, but also to the desire for becoming one with the absolute. The category of the ineffable, as construed by Plotinus, therefore encompasses both the sublime and beautiful.

Bowie (2003:43) describes the Kantian sublime as having "to do with things which are so big that they initially make us feel small". In Kant's (2008:23) own words:

[T]he sublime, in the strict sense of the word cannot be contained in any sensuous form, but rather concerns ideas of reason, which, although no adequate presentation of them is possible, may be excited and called into the mind by that very inadequacy itself which does admit of sensuous presentation. 
Kant's reasoning here is dialectical: the sublime reminds us of the limitations of our sensuous relationship to nature and gives us aesthetic pleasure via the initial displeasure at the reminder itself. In other words, the realisation of the limitations of sensuousness engenders the realisation that we also have access to forms of reason beyond sensuousness (Bowie, 2003:44).

The primary difference between the sublime and the beautiful is, according to Kant, to be found in the fact that in the sublime "the idea of freedom precludes all positive presentations" (Kant, 2008:29). Where the beautiful estimates the object in regard to its form, the sublime cannot - the sublime is beyond the sensuous. Judgements on the sublime involves the object's formlessness. Although both the beautiful and the sublime pleases "on its own account", the latter does so to a greater extent (Kant, 2008:23). In addition, although both the sublime and the beautiful pleases, pleasure in the beautiful is "positive" - life-enhancing and joyous, while pleasure from the sublime is "negative" - more like respect (Guyer, 1992:382).

In Plotinus' conception of the absolute, this distinction between the sublime and the beautiful is absent. Meditating on the ineffability of the One produces both awe and pleasure, both the experience of the transcendent as absolutely unknowable, and a view of the transcendent as a "supra-hierarchical summit that we may gradually hope to scale" (Milbank quoted in Lochhead, 2008:70).

Kant's philosophical distinction between the sublime and the beautiful not only marks the "subjective turn" in philosophy, but also the rise of the second broad area of importance for the ineffable aesthetics.

\section{From religion to aesthetics}

Although Kant himself did not consider music to be the "highest" art, his definition of the sublime in terms of unrepresentability provided the impetus for the radical reconfiguration of the status of music that took place in romanticism. The philosophical importance given to music towards the end of the eighteenth century can, according to this view, be directly attributed to the fact that music was seen to represent the non-representational, in other words, the ineffable. In this time music becomes significant, in the words of Bowie (2003:2), "as a means of understanding subjectivity". "Music", Bowie (2003:23) continues, "makes evident the fact that understanding subjectivity can never be fully achieved through theoretical articulation". The world can therefore not be exhausted by theoretical knowledge 
alone. Beyond the borders of theoretical knowledge Kant (2008:49) finds the "aesthetic idea":

... that representation of the imagination which induces much thought, yet without the possibility of any definite thought, i.e. concept, being adequate to it and which language consequently, can never quite get on level terms with or render completely intelligible.

The aesthetic idea can be equated with what Kant (2008:8) also calls the "universal voice" or the sensus communis, which ensures the universality of aesthetic judgments. ${ }^{1}$ As such, it is the imagination that stands at the root of all knowledge for Kant (Eagleton, 1990:102). The ineffability of the aesthetic idea therefore points towards a view of the subject as absolute. This idea not only supports Kant's insistence that the rational subject stands at the centre of the cognitive and moral worlds, but also pre-empts the importance of music for the romantics. Schlegel (quoted in Bowie, 2003:37), building on Kant's ideas, situates music at the moment of cognition of the subjective:

[1]f feeling is the root of all consciousness, then the direction of language [towards cognition] has the essential deficit that it does not grasp and comprehend feeling deeply enough, only touches its surface ... However large the riches of language offers us for our purpose, however much it can be developed and perfected as a means of representation and communication, this essential imperfection must be overcome in another manner, and communication and representation must be added to; and this happens through music which is, though, here to be regarded less as a representational art than as philosophical language, and really lies higher than mere art.

Schlegel's view of music as philosophy, situated as it is in the ineffability of its sonic reality, ironically removes music from the phenomenal world and devalues music as sound. Music, in Schlegel's "philosophical" sense, acts as a model for subjectivity - as a symbolic medium for self-cognition. Therefore, the ineffability of Kant's "aesthetic idea" is as much a move towards absolute subjectivity as it is a move to autonomous art.

1 When Kant says that the universal voice is only an idea (Kant, 2008:8), the "idea" referred to is in fact the "aesthetic idea", argues Guorova (2008). 
With the balance shifted to "pure" or "ideal" music, the holy trinity of nineteenth-century thought on music is born: autonomous music, ineffability, subjectivity. Or as Chua (1999:148) puts it:

The lack of self-presence became the zero-origin of music's autonomous generation; the lack of rational concept became the logic of a language beyond language; and its lack of visibility became the ineffable representation of the noumenal self.

The importance of the ineffable in romanticist thought on music can be drawn along two lines, both tied up with what Lydia Goehr calls music's emancipation from the extramusical. Goehr (1992:152-157) identifies two aspects of the romantic aesthetic that played an integral part in this emancipation - the transcendent move and the formalist move. The transcendent move culminated in the realisation that the value of art no longer lay in its ability to bring home religious or moral values, but that art was a pathway to a secular eternal, to a truth that transcends the worldly, to the ineffable. The formalist move, on the other hand, tried to bring music's meaning from the outside to the inside. Musical meaning no longer resided in representation, but was to be found in the "internal, structural coherence" of music.

For Goehr the transcendent and formalist move were instrumental in the construction of what she calls the "work-concept" 2 in music. As I will show, however, the fact that both these ideas are so closely tied up with the ineffable, suggests a deeper layer of significance that has mostly been overlooked by narratives on the emergence of the musical work. This significance, I believe, is the result of a complex process of mythmaking around music: a misconstrued portrayal of the absolute in music, which resulted in a quasi-religious authority being imposed on the musical work and the composer to the detriment of actual musical performance.

2 According to Goehr (1989:55) the concept of the musical work came into existence towards the end of the eighteenth century. Before this time music was understood mainly in terms of its social, religious or scientific function, and not as an autonomous art form. Thus a musical work is defined as "a composer's unique, objectified expression" and a "public and permanent artifact made up of musical elements". Furthermore, a musical work is "fixed with respect, at least, to the properties indicated in the score and is repeatable in performances". 


\section{The myth of music as absolute}

Levinson (1995), in a review of Diana Raffman's book Language, music, and mind (1993) comes to some baffling conclusions. Levinson finds Raffman's focus on the ineffable knowledge of, or through musical performances, or concrete musical events "surprising", and for philosophers of music, "ultimately unsatisfying". The reason for Levinson's surprise is that the "traditional notion of musical ineffability ... concerns ineffable knowledge of or through musical works". "The fact", he continues, "is that it is the ineffability resident in experience of musical works, not in experiences of their performances as such, that has motivated claims in aesthetics about what music imparts to us that cannot be verbally expressed, or perhaps expressed in any medium other than music":

That is to say, the ineffability of greatest interest, if it exists, resides in notatable, fully effable musical structures, rather than individual, maximally nuanced instantiations of those structures. The more important kind of ineffability in music, if it exists, concerns what music conveys, or at least gives the impression of conveying about human life: its pattern and dynamic, its attitudes and emotions, its conflicts and significances. The ineffability of what is grasped in auditing Beethoven's Piano Sonata Op. 90, or Schubert's 'Death and the Maiden' Quartet, or Mahler's Ninth Symphony, or Berg's Violin Concerto, is not a matter of, or in any way dependent on, the ineffability of the maximally specific pitches, rhythms, and dynamics by which a specific performance of those works acquaints or reacquaints us with them. (Levinson, 1995:201.)

It is clear here that Levinson underscores the superiority of the sublime over the beautiful, as proposed by Kant. The distinction Levinson makes between musical works "themselves" and performances of these works are peculiar, to say the least, and aligns surprisingly closely with Schlegel's idea of music as "philosophical language". The problem with this is, among others, that real, actual and live music is cast aside in favour of either the musical score, or even worse, the "idea" of the musical work. Even more disturbing is Levinson's claim that what music conveys about human life is to be found not in the actual experience of music, but through a supraaudible and ahistorical knowledge of "fully effable musical structures". Not only is such an argument elitist, it is also guilty of manifold other sins: depreciating the role of the listener in constructing musical meaning, encouraging score-based reflection on music, while ignoring the power of music in performance, assuming that all music is instrumental, and German, for that matter, and overlooking 
the historical and political real-life "work" that music does. "Music as philosophical language" absolutises music: in this sense, music is its own first cause, its truth-content is immanent and its significances are ineffable. Although Levinson's views, as a philosopher of music, is not paradigmatic of musicological thinking, the naturalness with which ideal music takes priority over actual musical sound in his argument is endemic to musicological discourse as a whole.

The myth of music as absolute can be explored by comparing the absolute subjectivity of the romantics to Plotinus' thinking about the absolute One. This is made possible by the fact that the romantics, for the most part, equated arguments for absolute subjectivity with arguments for music as philosophical language. 3

The language of the romantics mirrors that of Plotinus in many ways, most significantly so when the matter at hand is the correlation between the ineffable and the absolute. In a very neoplatonist manner Novalis (quoted in Bowie, 2003:78) describes the absolute "l":

I means that Absolute which is to be known negatively - what is left after all abstraction - what can only be known by action and what realises itself by eternal lack.

With these words Novalis endorses the logical link between ineffability and the absolute, which comes to the fore in the deficiency of the subject attempting to say the ineffable. There are,

Hegel is a notable exception here. Although he (Hegel, 1998) states that "the chief task of music consists in making resound, not the objective world itself, but, on the contrary, the manner in which the inmost self is moved to the depths of its personality and conscious soul" (Hegel, 1998:891), Hegel sees music as a subordinate manifestation of the truth. In addition, Hegel seems, contrary to the Zeitgeist, to prioritise music with words over instrumental music. A higher form of truth is possible in music with words, as instrumental music is only an expression of "feeling". On the other hand, music coupled with words "gives us distinct ideas and tears our minds away from that more dreamlike element of feeling which is without ideas" (Hegel, 1998:937). For Hegel it is not true that music can express things words cannot and he sees the unrepresentational nature of music as its essential limitation, as is evident from the following passage:

\footnotetext{
Especially in recent times music has torn itself free from a content already clear on its own account and retreated in this way into its own medium; but for this reason it has lost its power over the whole inner life, all the more so as the pleasure it can give relates to only one side of the art, namely bare interest in the purely musical element in the composition and its skillfulness, a side of music which is for connoisseurs only and scarcely appeals to the general human interest in art. (Hegel, 1998:899.)
} 
however, two key difference between the neoplatonic and romantic take on the absolute.

The first difference lies, in my view, in Plotinus' insistence on differentiating between the One and Intellect (Nous), even if the two are in many ways similar. For Plotinus the One is the first cause and therefore the originating principle of the Intellect. Because the One is absolutely singular and self-sufficient, needing nothing for its own existence, not even self-consciousness, it cannot be said to have consciously created or determined Intellect. Rather, Plotinus wants us to understand the relationship between the One and Intellect, and indeed the entire universe, as one of emanation. Plotinus explains the concept of emanation with the metaphor of a river overflowing and of light emanating from a beam. Without any conscious decision on the part of the One, it shares characteristics of itself with Intellect. In the words of Lekkas (2004:54) "it is not that the One is a higher version of Nous, but that Nous is a lesser version - 'an image' - of the One." Thus it can be said that Intellect is the One conscious of itself. This differentiation holds the belief in the absolute intact, without the One being lost in its own autonomy - not needing anything, but at the same time being totally superfluous.

The absolute of the romantics radically differs from this conception. The foundation for this difference can be found in the realisation, mainly as a result of the legacy of Kant, that there is no compelling guarantee that the coherence of the world is the result of divine creation (Bowie, 2003:3). With God taken out of the equation, a new absolute had to be found - the absolute "I".

The turn to absolute subjectivity is nowhere more evident than in the work of Fichte. Radicalising Kant's focus on the subject through his belief that the structures of self-consciousness mediate everything we can say about reality, Fichte's total world became the product of the I (Bowie, 2003:58). But for Fichte the absolute I is not fact, but action - the act of the I thinking itself (Bowie, 2003:63; Chua,1999:162). In this way the I becomes at the same time the absolute origin and the object of its reflection. At pains to disengage themselves from theological thinking, it was of paramount importance for the romantics to prove that subjectivity arose, as it were, from itself. Without a truly spontaneous turn to self-consciousness, self-consciousness would have had to be interpreted in terms of cause and effect, meaning that the I couldn't be absolute as it wasn't its own cause. 
This idea had a profound influence on nineteenth-century musical thought. The formalist move, referred to earlier, can be interpreted as the musical equivalent of Fichte's absolute subjectivity. For music to become truly absolute, it had to become a sign involved in what Chua (1999:171) calls the "double play of self-signification". Music could point towards the realm of the infinite only by referring to itself. It could only signify the absolute by being itself absolute. Because absolute music indicated infinity from within itself it was seen as poiesis ex nihilo - pure productivity. Music could therefore produce meaning through its own musical material. It could represent the outside without ever leaving the domain of insideness.

The "double play of self-signification" suggests a paradoxical relationship between ineffability and immanent meaning in music. Although music could represent the extra-musical by turning back onto itself, it was the sheer ineffability of music that gave it its cognitive content in the first place. Chua (1999:171) puts it this way:

Music is not only a sign that refers to the 'realm of the infinite', but seems to indicate that realm by referring to itself; in its semiotic play, music assumes an internal recognition of itself as absolute.

Fichte's philosophy of absolute subjectivity, on which the ineffability/ immanent meaning paradox is based, is, however, deeply flawed, as Hölderlin (quoted in Bowie, 2003:68) was first to recognise:

[Fichte's] absolute I ... contains all reality; it is everything, and outside of it there is nothing; there is therefore no object for this absolute I, for otherwise the whole of reality would not be in it; but a consciousness without an object is unthinkable, and if I am this object myself, then as such I am necessarily limited, even if it only be in time, thus not absolute; thus there is no consciousness thinkable in the absolute I, as absolute I (Ich) I (ich) have no consciousness, and to the extent to which I have no consciousness I am (for myself) nothing, therefore the absolute I is (for me) nothing.

Hölderlin is arguing here that the idea of a conscious absolute whether it be subjective or musical - is philosophically untenable. In the light of Plotinus' conception of the One, Hölderlin's criticism makes perfect sense. Plotinus' theory of emanation protects the absolute from dividing into itself, becoming conscious of itself, and thereby giving up its status as absolute. For, as Hölderlin points out, a truly absolute I would not be capable of consciousness as this 
would indicate some sort of need within itself - a need that would then have to be transcended.

A second point of divergence between the romantic and neoplatonic conception, concerns the distinction between the sublime and the beautiful. As noted above, Plotinus' One is both sublime and beautiful, both awe-inspiringly distant and, at least potentially, life-enhancingly close. On the contrary, Milbank (1998) argues that modernity and postmodernity "tend strictly to substitute sublimity for transcendence". Where once God was both sublime and beautiful "all that persists of transcendence is sheer unknowability or its quality of non-representability and non-depictability" (Milbank, 1998: 259). Ineffability divorced from the beautiful is what fuels the need for Fichte's self-conscious absolute in the first place. Without the beautiful, any absolute - whether it be the One, the self or music runs the risk of becoming so closed off to the world that it becomes irrelevant. On the other hand, the beautiful is invidious to an "internal recognition of itself as absolute", because the beautiful implies an embeddedness in the sensuous - the very thing that both absolute subjectivity and absolute music tries to escape.

Efforts to smooth over these errors in romantic and idealist thought have resulted in an elaborate myth being constructed around absolute subjectivity, and through the appropriation of poets and artists, around music. Through the fallacy of the musical absolute, contained in the desire for the ineffable, romantic musical experience became, according to Schleuning (as paraphrased by Erauw, 1998:114) an autonomous religious practice that was part of the process of secularisation. With subjectivity gaining leeway over traditional religion, music has been ascribed many of the categories and roles traditionally associated with church worship (Erauw, 1998:114; Goehr, 1992:157). Willem Erauw (1998:115) contends that the "secularized religion of music" has its roots not only in secularisation, but also in the Judeo-Christian tradition itself, primarily through a suppression of the sensuous implicit in the JudeoChristian worldview. This suppression has resulted in a modern concert hall etiquette where a bodily experience of music is actively discouraged. In addition, Dahlhaus (1991:80) argues that Herder's view of aesthetic contemplation as "devotion" or "religious awe" is intimately tied up with music's ineffability:

Only if wordless music 'elevates' itself above speech, instead of remaining beneath it, can one sensibly allow elevation to religious devotion and the contemplation of absolute music to merge into one another. 
Claims of the ineffability of music therefore not only locate music as absolute, it confers on music a quasi-religious authority, which results in an ungrounded faith in the power of music to be selfreferential and in the mastery of the composer to bring mankind closer to experiencing infinity, as Hoffman would have us believe (Charlton, 1989:234-251).

\section{Challenges for musicology}

Musicology stands in an uneasy relationship to the myth of music as absolute. In the current intellectual climate, with its preoccupation with place and particularity, it is becoming increasingly unfashionable to read things divorced from their contexts. The concomitant trend in musical historiography has been to recognise the importance of contexts and the difficulties in locating them. On the other hand, musicology remains heavily indebted to the myth of music as absolute, as Erauw (1998:115) argues:

If musical experience had not become a sacred autonomous world of sounds, which has been praised and sanctified as a mirror of heaven since the late 18th century, the intellectual and spiritual discourse would probably never have developed in which music is perceived as something very serious, and thereby as the basis for a more scientific approach. In other words, whether they are happy with the notion of a musical work or not, scholars in musicology are all still heirs to romantic aesthetics.

The ineffable continues to survive as a heirloom of romantic aesthetics in current musicology - especially in musical hermeneutics and some so-called "contextual" approaches to music.

In her article Abbate (2004) argues that the ineffability of music, although generally scorned by hermeneuticians of music, is in fact a necessary prerequisite for hermeneutic inquiry. This might seem like a paradoxical line to take: how can hermeneutics, which presupposes an immanent content to music, be indebted to views of the ineffability of music which seem to deny that such immanence exist? The ineffability-immanence paradox, however, is central to the romantic conception of the musical work through the double play of self-signification.

The idea behind musical immanence is that sonic traces of history are encoded in music and that it is possible to decode these latent meanings (Nattiez, 1990:28-30). Fundamental to this line of thought is that the composer has no conscious knowledge of encoding the 
music with these meanings. Rather, it is as if the musical material itself creates distinguishable links with the political, social and intellectual climates in which it took form. Adorno (2002:391, 393) shares a similar view of the nature of the musical work of art: it is precisely music's self-referentiality that allows for connections with the outside to be formed.

No matter where music is heard today, it sketches in the clearest possible lines the contradictions and flaws which cut through present-day society; at the same time, music is separated from this same society by the deepest of all flaws produced by this society itself.

[M]usic fulfils its social function ... when it presents social problems through its own material and according to its own formal laws - problems which music contains within itself in the innermost cells of its technique.

In recent times, however, it is the very distinction between the music itself and the extra-musical that has come under attack. Taruskin (1997), for instance, argues that the distinction between the musical and the extra-musical is false; that one cannot exist without the other. He sees both extremes of the text/context debate as delimiting. "On the one hand", writes Taruskin (1997:480),

... are those who would prefer to simplify matters by denying the very existence (or the 'reality') of a latent content and claiming for music the status of an inherently or ideally nonreferential medium, unattached to the wider world and beatifically exempt from its vicissitudes [...] On the other hand are those who not only acknowledge the immanence of a latent musical content but seek, or presume, to define it, to fix it, to make it manifest, to have it name names and propound propositions.

Instead he contends that latent musical meaning should neither be negated nor "successfully administered"; that the value of music is best appreciated when latent meaning is "acknowledged but contested" (Taruskin, 1997:481). With these kinds of arguments many myths have been displaced. The interpreter is given room to play an active role in creating meaning and the idea that musical meaning cannot be fixed or owned is developed.

The central tenet that music has immanent cognitive content has, however, miraculously survived this onslaught in the form of hermeneutics. Kramer (1990:1; 2003), for example, sees the claim that music has discursive meanings as a necessary condition for the 
hermeneutic project; and it is easy to see why. For any process of decoding to take place there must be something to decode in the first place.

Precisely how are musical works supposed to represent the social conditions of their production and how do they manage to reveal aspects of the composer's identity or philosophical beliefs? In what sense can Stravinsky's music be seen as the sonic trace of a "stripdown" from humanism to biologism in early twentieth-century music, and The rite of spring and Svadebka as a reflection of the composer's "lifelong antihumanism" and anti-Semitism, a "celebration of the unquestioned subjection of human personality to an implacably demanding ... social order", as Taruskin (1997:382) would have us believe? The error that enables Taruskin to persist in claiming a cognitive content for music, is the fact that he falls into the trap of the double play of self-signification. In the light of the ineffability/immanent meaning paradox no real distinction can be made between viewing the musical work as an ineffable "nonreferential medium" devoid of latent content and claiming that it has a manifest latent content, for both these views spring from the same source - a view of music that relies on insideness. Indeed, the ineffability of music is the required first step for music to be able to represent anything.

The romantic legacy of the ineffable is also evident in some socalled "contextual" approaches to music. In his appeal to shift the focus from a "dogged concentration on internal relationships within a single work" to a more "contextual" approach, Kerman (quoted by Christensen, 1993:21) remarks that "by removing the bare score from its context in order to examine it as an autonomous organism, the analyst removes that organism from the ecology that sustains it". The musical work therefore becomes a product of its surroundings, determined by the "environmental factors" that shape its physiology. While the contextual move has led to a new understanding of the embeddedness of music in society and has, in so doing, ridded musicology of some of its grand narratives, the "contexts" of musical works have in other cases become the hiding place for many of the ideologies that the new musicology has tried so hard to eradicate. A poietic definition of context keeps the glass house of the composer god intact.

Kramer's contextual approach unravels with LaCapra's recognition that the context does not exist, but that it is in itself a kind of text that relies on interpretations rather than descriptions. Furthermore, that the "problem in understanding context ... is a matter of inquiry into 
the interacting relationships among a set of more or less pertinent contexts". "Context" thus arises from a comparative exercise rather than an objective description (LaCapra, 1983:95-96). Along the same lines, White (quoted by Zammito, 1993) states that
... it is misguided to suppose that this context, the 'historical milieu', has a concreteness and an accessibility that the work itself can never have [...] The historical documents are not less opaque than the texts studied by the literary critic. Nor is the world those documents figure more accessible. The one is no more 'given' than the other.

Finding the "context" that predetermines and shapes the musical work is therefore not only a methodological problem, but an epistemological impossibility.

Trying to locate the "social context" of a work exclusively in the moment of production, at the expense of the social contexts that make up the afterlife of a work, reveals a series of fundamental beliefs about the nature and purpose of musical works, most of which can be extrapolated from this highly problematic passage by Tomlinson (1988:121):

We study, or should study works of art as records of human aspiration, achievement, and meaning in contexts different from our own. We should cherish them for what they tell us about the diverse creative acts that gave rise to them. When instead we view them ahistorically - as aesthetic objects uprooted from some context that we believe engendered them and transplanted into our own cultural humus - then we forfeit the possibility of conversing meaningfully with their creators. With easy but all-too-familiar meanings we talk mainly among ourselves, reflected in the work, and not with the work's creators shining through it. The work is a mirror rather than a magnifying lens, so to speak. And by regarding it as a mirror we give up or at least drastically limit our ability to broaden our world of discourse.

The fundamental fallacy of poietic reasoning is the assumption that an "ahistorical" approach to musical works equals an "aesthetic" one, where works are seen as abstract, contextless objects. In other words, that any approach that doesn't locate the primary meaning of a musical work within the context of its origin, necessarily leads to aestheticism. Tomlinson's (1988) view of the historical precludes 
any presentist 4 understanding of music. If it is limiting (read: wrong) to "transplant" music into a different "cultural humus", the entire project of reception histories is doomed to fail. The implication of Tomlinson's view is that reception histories are ahistorical or, at least, that they tell the wrong histories. This kind of reasoning exemplifies musicologists' obsession with the moment of production, the status and authority of the composer and a near denial of the fact that Western canonic music has played, and continues to play, a significant part in constructing social identities in contexts other than that of their own production.

The way Tomlinson ignores reception history reveals a much more "aesthetic" approach to musical works than he would have us believe. Focusing on poietic processes freezes the latent content of music in a specific time and place and upholds the work of music as an almost religious artefact not to be touched or tampered with. It implies that musical works have a stable ontology - an abstract reality removed from its performance and its "social context". If musical works are "records of human aspiration, achievement, and meaning", they should have an immanent, unchangeable truth-content. "Social histories" in this sense become add-ons to traditional musical historiography. Behind the smokescreen of context, and with the use of a new socially informed vocabulary, the double play of ineffability and immanence is invoked yet again.

The only real alternative is to see performance as the primary object of study, focusing on the local and once-off meanings that are thus created. Such a project would not be without sacrifices, as Derrida (1991:221) recognises. In order to answer the question What is poetry?, in order to understand it in different social contexts, "you will have had to disable memory, disarm culture, know how to forget knowledge, set fire to the library of poetics. The unicity of the poem depends on this condition. You must celebrate, you have to commemorate amnesia ..."

The shift to performance insists on the rejection of a set of beliefs a step, as Abbate (2004:510) points out, that has a wide range of implications.

$4 \quad$ A presentist or "whiggish" history (often used in derogatory terms) is one where history is told from a contemporary perspective, using concepts that might have been foreign to people living at the time. In musical discourse a presentist approach will be one that focuses on music's role in contemporary society, rather than trying to reconstruct the context in which it was conceived. 
[F]ixing upon actual live performances would mean embracing the drastic, a radical step. There is no a priori theoretical armor. In practical terms, it would mean avoiding the tactile monuments in music's necropolis - recordings and scores and graphic musical examples - and in the classroom this is nearly impossible. In some larger sense it might even mean falling silent, and this is difficult to accept because silence is not our business, and loquacity is our professional deformation.

Forgetting, then, and falling silent. Forgetting, first of all, the "authorfunction", the poietic, the authority of the composer. Secondly, the musical work with its double play between ineffability and immanent meaning.

The author-function, writes Foucault (1991:107-108), points not necessarily to the creator of a text, but serves to characterise "the mode of existence, circulation, and functioning of certain discourses within a society".

[T] he fact that the discourse has an author's name ... shows that this discourse is not ordinary everyday speech that merely comes and goes ... On the contrary, it is a speech that must be received in a certain mode and that, in a given culture, must receive a certain status.

Once the poietic is revealed for what it is - a mechanism for justifying privileged discourses in society - the ramifications of the denouncement of the authority of the composer come to light.

For Barthes (1977), abandoning the author-function first of all changes the temporality of a text. Because the author can no longer be seen as antecedent to the text, as its past, the reader becomes the ultimate architect of the context in which it is understood - a complex network of triggered memories, arbitrary connections and past experiences. Just as Cook (2006) sees performance as the abolishment of the text/context distinction, the act of reading - the performance of the text - becomes the context in which it is understood. The importance of the text, and its ultimate "meaning", no longer rests within the text itself, but in the contexts that stick to it.

In musical terms that would result in the abolition of any direct link between the composer's prior life, the social circumstances that engendered the production of the musical work and the musical work itself. In fact, music ceases to be "a work" at all. "Work" in an aesthetic sense can in Martin's words (2002), only refer to "people 
acting together to produce 'works"' or to "meanings as created in and through the interpretative 'work' of individuals in interaction with each other". Therefore, with the poietic out of the equation, the ontology of the musical work necessarily alters as well. An aesthetic inquiry into the social production of meanings deals inescapably with an "unstable work, one that recedes or 'vanishes' before our eyes as it encounters the different preconceptions of particular cultural communities", as Samson (2001) puts it. As Barthes conceives it, music is always in the present, always performative. The only context that matters is the present.

Falling silent, the second implication of the performative turn according to Abbate (2004), is more problematic. Nicholas Cook's (2006) attempts to analyse performance illustrates musicology falling silent. His use of graphs, dots, lines and waves to compare performances, the particular "cultural significance" of which is relegated to future inquiry, is mute when it comes to meaning in music (Cook, 2006). Abbate's version (2004) is equally silent, in content and metaphor: she reconfigures the ineffability of music as its indeterminacy and the inability of the body to speak of its experience of music as "material reality". 5 If musicology is falling silent, is it because it conceives of music as personal, meditative and non-interactionist, or because its traditional methods of inquiry cannot capture performance, because it does not know how to deal with the presence of music?

Both Cook (2006) and Abbate (2004) fail to connect to the reality of performance. Cook hides away in the throngs of historical recordings, constructing a glass box around the performer to superficially separate him from others. Abbate zooms in on the personal experience of the listener. Both ignore the fact that performance involves more than one party - it revolves around sound, not silence, talking, not ineffability. As ethnomusicologists have long since recognised, performance space lends itself to the re-enactment of social patterns that have a life beyond the four walls of the concert hall; that when negotiating musical performances people do not leave their political allegiances behind, but act them out through music. This is why musical performances not only mirror society, but play an active role in creating patterns of interaction. 6

5 Cf. Berger (2005) on the aestheticism of Abbate's approach.

6 Cf. Attali (1985), Stokes (1994) especially the chapter by Bailey on Afghan national identity, as well as Kaemmer (1993). 
There is no easy way out of the double play of ineffability and immanent meaning. Metamorphosis is required: the shedding of an old skin of fundamental beliefs in favour of a new one. A genuine concern with context and the social dimension of music cannot sit together comfortably with romantic notions of the ineffability of music. In order to detranscendentalise musical meaning, performance needs to stand at the centre of musicological inquiry.

\section{List of references}

ABBATE, C. 2004. Music: drastic or gnostic? Critical inquiry, 30(3):505-536.

ADORNO, T.W. 2002. On the social situation of music. (In Leppert, R.D., ed. Essays on music: Theodor W. Adorno. Berkeley: University of California Press. p. 391-436.)

ATTALI, J. 1985. Noise: the political economy of music. Trans. by B. Massumi. Manchester: Manchester University Press.

BARTHES, R. 1977. The death of the author. (In Heath, S., trans. Image-musictext. London: Fontana. p. 142-148.)

BERGER, K. 2005. Musicology according to Don Giovanni; or, Should we get drastic? Journal of musicology, 22(3):490-500.

BOWIE, A. 2003. Aesthetics and subjectivity: from Kant to Nietzsche. Manchester: Manchester University Press.

CHARLTON, D. 1989. E.T.A. Hoffman's musical writings: Kreisleriana, the poet and the composer, music criticism. Cambridge: Cambridge University Press.

CHRISTENSEN, T. 1993. Music theory and its histories. (In Hatch, C., ed. Music theory and the exploration of the past. Chicago: Chicago University Press. p. 9-39.)

CHUA, D.K.L. 1999. Absolute music and the construction of meaning. Cambridge: Cambridge University Press.

COOK, N. 2006. Shifting the object: towards a musicology of performance. Paper presented at the Graduate Colloquium at Cambridge University.

DAHLHAUS, C. 1991. The idea of absolute music. Trans. by R. Lustig. Chicago: University of Chicago Press.

DERRIDA, J. 1991. Che cos'è la poesia? (In Kamuf, P., ed. A Derrida reader: between the blinds. New York: Columbia University Press. p. 221-237.)

EAGLETON, T. 1990. The ideology of the aesthetic. Oxford: Blackwell.

ERAUW, W. 1998. Canon formation: some more reflections on Lydia Goehr's imaginary museum of musical works. Acta musicologica, 70(2):109-115.

FOUCAULT, M. 1991. What is an author? (In Rabinow, P., ed. The Foucault reader. Harmondsworth: Penguin. p.101-120.)

GOEHR, L. 1989. Being true to the work. Journal of aesthetics and art criticism, 74(1):55-67.

GOEHR, L. 1992. The imaginary museum of musical works: an essay in the philosophy of music. Oxford: Clarendon.

GOUROVA, M. 2008. The aesthetic idea and the unity of cognitive faculties in Kant's aesthetics. Georgia State University. (M.Phil. thesis.) http://etd.gsu.edu/theses/ Date of access: 2 Jun. 2009. 
GUYER, P. 1992. The Cambridge companion to Kant. Cambridge: Cambridge University Press.

HEGEL, G.W.F. 1998. Aesthetics: lectures on fine art. Vol. 2. Trans. by T.M. Knox. Oxford: Oxford University Press.

KAEMMER, J.E. 1993. Music in human life: anthropological perspectives on music. Austin: University of Texas Press.

KANT, I. 2008. The critique of aesthetic judgment. Trans. by J.C. Meridith. http://ebooks.adelaide.edu.au Date of access: 20 May 2009.

KRAMER, L. 1990. Music as cultural practice. Berkeley: University of California Press.

KRAMER, L. 2003. Subjectivity rampant! Music, hermeneutics, and history. (In Clayton, M., Herbert, T. \& Middleton, R., eds. The cultural study of music: a critical introduction. New York: Routledge. p. 124-135.)

LaCAPRA, D. 1983. Rethinking intellectual history. London: Cornell University Press.

LEKKAS, G. 2004. Plotinus: towards an ontology of likeness (On the one and nous). International journal of philosophical studies, 13(1):53-68.

LEVINSON, J. 1995. Review: language, music and mind. Mind, 104(413):197202.

LOCHHEAD, J. 2008. The sublime, the ineffable, and other dangerous aesthetics. Women \& music, 12:63-74.

MARTIN, P.J. 2002. Over the rainbow? On the quest for the social in musical analysis. Journal of the Royal Musical Association, 127:130-146.

MILBANK, J. 1998. Sublimity: the modern transcendent. (In Heelas, P., ed. Religion, modernity and postmodernity. Oxford: Blackwell. p. 258-284.)

MOORE, A.W. 2003. Ineffability and religion. European journal of philosophy, 11(2):161-176.

NATTIEZ, J-J. 1990. Music and discourse: towards a semiology of music. Princeton: Princeton University Press.

O'MEARA, D.J. 1993. Plotinus: an introduction to the Enneads. Oxford: Clarendon.

O'MEARA, D.J. 2000. Scepticism and ineffability in Plotinus. Phronesis, 45(3):240-251.

PLOTINUS. 1988. Enneads. Trans. by A.H. Amstrong. Cambridge: Harvard University Press.

SAMSON, J. 2001. The musical work and nineteenth-century history. (In Samson, J., ed. The Cambridge history of nineteenth-century music. Cambridge: Cambridge University Press. p. 3-54.)

STOKES, M., ed. 1994. Ethinicity, identity and music: the musical construction of place. Oxford: Berg.

TARUSKIN, R. 1997. Defining Russia musically. Princeton: Princeton University Press.

TOMLINSON, G. 1988. The historian, the performer, and authentic meaning in music. (In Kenyan, N., ed. Authenticity and early music. Oxford: Oxford University Press. p. 115-136.)

ZAMMITO, J.H. 1993. Are we being theoretical yet? The new historicism, the new philosophy of history, and "practising historians". Journal of modern history, 65:783-814. 


\section{Key concepts:}

absolute music

ineffability

Plotinus

romanticism

Kernbegrippe:

absolute musiek

onsegbare

Plotinus

romantiek 